Вісник Львівського університету. Серія філос.-політолог. студіі. 2020. Випуск 31, с. 32-39

Visnuk of the Lviv University. Series Philos.-Political Studies. Issue 31, p. 32-39

UDC 291.14:291.37

DOI https://doi.org/10.30970/PPS.2020.31.4

\title{
WORSHIP PRACTICES IN THE FIELD OF TRADITIONAL BEING OF RELIGION
}

\author{
Christina Kvasha \\ Zhytomyr Ivan Franko State University, \\ Department of Philosophy and Political Science \\ Velyka Berdychivska Str., 40, 10008, Zhytomyr, Ukraine
}

The article analyzes the semantic load of the concept of religious cult, which is manifested as a set of rituals and ceremonies aimed at honoring God by the followers of a religion at the socio-cultural level. It is shown that the basis and external manifestation of a religious cult is a ritual, which, in its turn, may involve the whole range of ritual actions. The concepts of ritual and religious ritual are distinguished. It is established that the ritual is a clear order of ritual actions, which a human must follow regardless of the inner state of the soul and personal experiences. The multifunctionality of the ritual is emphasized, which is an effective factor in preserving the community in a crisis situation, a means of transmitting social heritage and preserving tradition. Moreover, the ritual, appearing as a system of various sign systems, forms a sense of social well-being and uniqueness. Distinguishing from the semantic cognation of religious rites and rituals in the ancient Slavic and Christian traditions, their substantive and hierarchical difference is proved, emphasizing that the rite should be considered as an order of external supportive actions that either accompany the ritual or are aimed at sanctifying vital needs of a human or a community.

The relatively free space of comprehension and interpretation of religious practices in the mundane life of the faithful has led to the variable nature of practices, the demonstration of the sphere of interaction of church and secular dialectics. The peculiarity of the faithful mundane life is the focus on the sacraments, the characteristic feature of which is the dominance of the ritual and ceremonial component of religiosity and the identification of the essence of Christianity mainly with the external manifestations of the church. The analysis of mundane practices of the faithful of different religious organizations demonstrates not only the combination of secular and ecclesiastical dialectics, but also reveals the degree of flexibility, adaptability of practices to the socio-cultural environment. The study of religious practices makes it possible to determine the overlap points of secular and clerical dialectics in the ethno-confessional field.

Key words: religious practices, rite, cult, ritual, Christology, religious identity.

The mundanity, as an objective world and an a priori condition of human existence, is a state of natural attitude, a defining obvious reality that does not raise doubts and does not require reflection. The objectification of religious rites in the faithful's mundane life has not been studied for a long time because of the lack of innovation in the religious practices of early Slavic and Christian religious organizations, and by the reason of the growth of conservative and fundamentalist sentiments that determine political behavior and political processes.

The actualization of this phenomenon in modern researches is manifested, on one hand, in the growth of conservative and fundamentalist sentiments that determine religious behavior and religious processes, and on the other hand, in the realization of mundane life as a form of social reality that generates means of comprehending the world and forming its images. Despite the complex intertwining of various contours and orders, it is a holistic, orderly and functional universe that encompasses the existence of all other well-known human realities.

The study of religious rites in the faithful's mundane life involves the analysis of everyday consciousness, which includes folklore influences, synthesis of religious ideas with non-Chris-

(C) C. Kvasha, 2020 
tian, scientific phenomena, the identification of the specifics of religious stereotypes, the reception of mundane mythological forms etc.

The clarification of the essence of religious rites, which usually contain dialectic forms and function in the dichotomy of religious and secular contradictions, provides the realization of religious rites as a means of including supernatural thing in the sphere of mundane life. Therefore, the study of religious rites and their implementation in the mundane life of the religious community makes it possible to clarify the ontological dimension of the mundane life of the faithful and contributes to the development of socio-humanistic dialectic of the mundane life.

The study of religious rites as a type of social actions in the mundane life of the faithful remains relevant in native religious studies. There is an essential need to analyze religious practices as part of the religious relations of Christians. Religious relations are formed in accordance with the consciousness of the faithful, are implemented and function due to religious activities. They are carried by individuals, communities and organizations that express real relationships connecting to the faithful. The peculiarity of religious relations is the acquisition of the object form due to things of animate and inanimate nature. Their mediation is getting figurative forms through the use of images-symbols of God.

The comprehension of the essence of religious practices in the dimensions of human existence is impossible without a proper understanding of the concept meaning. In the native scientific dialectic, religious practices are analyzed in the context of social practices. In particular, T. Ratushna points out that religious practices are determined by widely-accepted forms and types of human life [1, p. 63]. According to the researcher, human activity is regulated by the individual or collective performance of religious precepts, rites or ceremonies. Instead, other researchers point out that religious practices are based on actions that shouldn't follow canonical precepts.

A comprehensive study of the religious rites of Christian churches is based on the need to determine the features of the practical dimension of religion in the mundane life of a faithful. A lot of researchers have referred to the analysis of rites and rituals, but they have only approached the theoretical level of study of these phenomena, focusing on historical or functional approaches. In many cases, researchers did not distinguish between religious rites and rituals, using common church terminology. Various aspects of this problem are approached by the authors in works devoted to the problems of the cultural process, spiritual life or artistic culture. The analysis of these issues is revealed in the works by V. Davydovych, S. Krymsky, V. Mazepa, V. Malakhov, M. Tarasenko and others. The problem of rituals is covered in the works by I. Sukhanov, V. Plakhov, V. Chernyshov. The rituals of functional perceptive were studied in the works by V. Toporov, M. Eliade, E. Taylor, E. Durkheim.

The works of the authors, who are focusing on individual manifestations and peculiarities of the functioning of religious practices in different historical and socio-cultural environments, are of great importance. Among them it is significant to mention the works by O. Hoffman, L. Gumilev, V. Emelyanov, K. Levi-Strauss, V. Rudnev, S. Tokarev and others. It should be mentioned that most studies, devoting to this issue, pay considerable attention to specific historical religious practices, especially rites and rituals, which makes it impossible, in our opinion, to fully reveal the analyzed phenomenon.

Among native researchers, we mention the works of those authors who have thoroughly studied and analyzed religious rites through the prism of religious practices of Christian churches. In particular, Yu. Boreyko researched the sphere of interaction of the social and supernatural worlds, which encompasses everyday consciousness, mundane practices, relations and communications in the religious community. He revealed the peculiarities of the Orthodox religious choice, confessional affiliation in modern realities, the identity of Ukrainian faithful in terms of common 
problems for Orthodox jurisdictions, which are manifested in the mundane life of communities as centers of church society.

M. Petrushkevich's research, which is devoted to religious and ritual communication as a process of exchange of certain feelings and knowledge of the faithful, is valuable for our work. According to the researcher, such communication is possible only if the individuals, involved in it, establish not only mutual understanding between each other, but also the consonance of viewpoint regarding the religious and emotional content of a ritual act, when the faithful's beliefs concerning values coincide. Reflecting such values through symbolic means that affect the emotional and sensory sphere of people, rituals in this way stimulate the emergence and development of feelings, experiences and moods that correspond to the values. As M. Petrushkevich points out, interpersonal communication often undergoes constant control. Gradually, a number of stereotypes and cliches emerge in such communication; its participants don't become so much active communicators as passive reproducers of communication standards.

Equally important for our study is the work by V. Kondratieva, who substantiated the essential difference between ritual in archaic, pre-modern and modern societies. The researcher identified the need to distinguish between the concepts of "ritual" and "religious ritual", pointing out that the ritual is a clearly established order of ritual actions that an individual must follow regardless of the inner state of the soul and personal experiences. According to V. Kondratieva, religious ritual should be considered as a clearly established procedure, which should result in a meeting with the numinous. We share the author's position that religious practices are aimed at the formation of confessional religiosity, which involves the recognition of certain external patterns, thereby contributing to the consolidation of the group. Thus, religious practices are not appeared to be as a monological connection between a religious text and practice, but as a dialogical system that has no predetermined meaning.

The way we see, religious practices are formed at the level of behavior that integrates human actions in the religious sphere. Such actions include helping and sympathizing with the needy, philanthropy, visiting holy places, reading religious literature, the crucession etc. Furthermore, as L. Rezanova points out, there is a danger of leveling the essence of religious practices, which are associated with the celebration of important family events on religious bases (baptisms, weddings, etc.). According to the researcher, holding such events in the family circle indicates a low level of religiosity and the lack of a theoretical level of religious consciousness. The motivation for these practices is primarily the desire to communicate, a sense of belonging to a religious group, meeting aesthetic needs and gaining new impressions and feelings [2, p. 95].

From this perspective, it is important to realize the relationship between religious practices and religious experience. In the philosophical sense, experience is considered as knowledge, embedded in the mind of the subject and is expressed by certain feelings in contact with the surrounding reality [3, p. 112]. Instead, V. Moskalets considers that religious experience is the process of emotional and mental activity of the subject, which rethinks the basic dogmatic provisions of religion in relation to its own values [4, p. 229]. We share the V. Kondratieva's statement that religious experience belongs to a greater extent to the category of religious psychology, which reflects the mental state of the individual regarding the transcendent $[5$, p. 43]. Therefore, the category of religious practices is becoming an integral part of the religious sociology, which studies the interaction of religion and society and determines its impact on the social behavior of individuals, groups, communities.

The cult (ritual) activity is an integral part of religious practices. According to Religious Dictionary, "religious cult is interpreted as a system of religious actions, objects and symbols, which were ethno-confessionally oriented, tested and, if necessary, changed in religious prac- 
tices" [6, p. 172]. The definition of "religious cult", proposed by D. Beznyuk, who emphasizes that religious cult appears as a form of religious action, which is manifested as a set of specific actions (rituals, rites, ceremonies) encouraged by the relevant doctrine and aimed at the sacral sphere, corresponds to the above-mentioned one [7]. Developing the opinion, M. Kunzler points out that the direction and meaning of religious worship may differ significantly in different types of religion, but the essence of religious action expresses the attitude to the saints and the Absolute, which affects an individual and consequently they feel dependent, because it provides them with life. Sacramental means caring, mainly precautionary behavior towards the saint and the Absolute, in order, on one hand, to preserve its sanctity, and on the other hand, to protect the mortal and burdened with guilt from the All-Holy and All-Pure [8, p. 24-25]. The Old Testament Israelites believed that the cult was established by God to communicate with people [8, p. 25].

From our point of view, a thorough definition of religious cult was proposed by the theologian O. Kirlozhev, who, starting from the etymological origins of this concept (derived from Latin cultus - veneration, worship), offered a broad and narrow interpretation. In a broad sense, the scholar emphasizes that a religious cult is worship, while in a narrow sense, it is a set of religious actions that express the worship of God or gods by believers of a religion [9]. Considering the specifics of religious worship, emphasizing the regional and religious differences of religious practice, O. Kryzhelov emphasizes that religious worship has both "vertical" and "horizontal" dimensions, on one hand, it expresses the deep religious need of an individual, and on the other hand, the need for their personal and social life to receive sacral circumstantiation and justification. After all, despite the fact that secularized culture has preserved many rituals and feasts of religious origin, though, in most cases, the attitude to religious worship is the criterion for distinguishing between religious and post-religious consciousness.

Thus, the concept of "religious cult" includes activities aimed solely at the perception of sacred and the formation of religious experience (sacred texts, prayers, rituals and ceremonies). In modern historical and socio-cultural conditions of human existence, the religious cult in its own sense of its content exists only within religious communities. The first and main form of its external manifestation is a ritual. Regarding to the latter one, it is accepted to consider the form of symbolic action which expresses connection of the subject with system of social relations and values and is deprived of any utilitarian or self-important value.

The statement of scholars, which emphasizes the fact that religious acts are embedded certain religious beliefs of a sacral nature is of significant importance for out study [10, p. 264]. Cult activities include prayers, sacraments, rites, religious feasts, which are integral part of the practical and spiritual entry of an individual into the religious world. A. Kolodnyi interprets the religious cult as a system of religious actions that have an ethno-confessional orientation and evaluation in religious practices over time. According to the researcher, the main form of external expression of the cult is a ritual. Its main features include, first of all, the unification of a collective or religious group and categorical self-identification. In this context, we share the definition proposed by I. Bogachevska, who considers the ritual as a communicative formation, which arises on the basis of social actions of a symbolic direction [11, p. 136].

Religious ritual, as a phenomenon of public life, regulates the order and nature of the actions of worshipers during the worship. Despite the external semantic simplicity of the concept, "ritual" has still a number of contradictions. They are considerably due to the fact that in foreign scientific literature, the terms "ritual" and "rite" are considered identical. This trend is due to the Latin origin of the word ritual - "ritualis", which meant ritual. European intellectual tradition has led to the fact that in the 90 s of the twentieth century in the native and Russian scientific literature these concepts began to be considered as synonymous. From our point of view, this approach 
is not entirely correct, because as noted by O. Sadokhin, "the rite is the peak of ritual action" $[12$, p. 230], which can be considered as a rule or procedure for conducting a religious or secular act by an official representative of the church or state. Along with the above-mentioned, there are significant methodological difficulties in elucidating the content of religious ritual, due to the fact that in Soviet philosophy and ethnography there was a clear intention to identify the ritual with custom. However, from our point of view, the ritual is just a kind of custom.

Regarding to the ritual, the method of performing the action is devoid of direct expediency and is only a designation (symbol) of certain social relations (the existing social order, the recognition of any values or authorities, etc.). Commonly, such actions are combined with actions aimed at the practical transformation and the use of a particular object. The roots of the word ritual "ritualis" go back to Sanskrit, within which the root "ar" meant "to set in motion, to move". In turn, the word "rita" (Rta) as an adjective and even more so an adjective meant "appropriate, correct", and as a noun "law", "order", "truth", "sacred rite" and "sacrifice".

As for the modern scientific term "ritual", in fact, it is derived from Latin, which has the noun ritus - "rite, service" and the adjective ritualis - "ritual" is formed on its basis. Addressing to the historical and etymological origins of the word, ritual helps better understand the definitions proposed, for instance, in the glossary by D. Ushakov, where a ritual is considered as an established order of ritual actions in the performance of any religious act. It is significant that an individual must comply with these established ethics rules in specific situations, despite the inner state of the soul [13]. We find a similar definition in the glossary by S. Ozhogov and N. Shvedova [14]. O. Baiburin makes an important clarification in realizing the content of the ritual. Along with the above-mentioned, he emphasizes that the ritual can be considered as one of the means of transmitting knowledge and information [15].

The English scholar W. Robertson-Smith is considered to be the key originator of ritual theory. In his work "Lectures devoting to the religion of the Semites", it was him to deduce that any religion consists of beliefs (or dogmas) and certain ethics and ritual practices. He also points out that the rite is not associated with dogma, but with the myth, namely the rites and rituals determine the meaning of the myth, because the myths that explain the rite, are being changed with the ages in accordance with ideologies, and the rites remain unchanged. Therefore, to reveal the essence of the rite, it is necessary to turn not to the myth, but to explore the real life of society [16].

The concept of "ritual" is much broader than the concept of "rite", which appears as an external manifestation of the ritual. Each ritual may include one or more rites. The legitimacy of our assumption is fully confirmed by E. Taylor, who emphasizes such rites as "prayer, sacrifice, fasting (and other means of artificial arousal of ecstasy), turning to the east, purification" in "Myth and Rite in Primitive Culture" [17, p. 214]. In fact, most rituals are accompanied by several rites. The latter appears as a holistic system of prescriptions and rules that determine the order of accession to the numinous (saint). The rite, being the external manifestation and integral part of the ritual, is traditionally considered as an external expression of the internal content of any religious act.

The religious activity is the main type of expression of the spiritual life of the society which is subject to the goals, interests and needs of religious relations. At the same time, religious relations are not limited to the religious sphere, but interact with the structural components of social relations. Thus, religious relations are a condition for the further development of social relations. According to E. Durkheim, the decisive factor in religion is not beliefs and dogmas, but rites and rituals. It is in cultic activities that the community is able to open the way to sacred objects, while ensuring a return to the mundane world. Religion, in this context, is a phenomenon 
in which the sacred is expressed as a basic social value. Cult action is an act through which society asserts itself as a community, namely realizes self-identity [18, p. 229]. From this perspective, the scholar deduces that the purpose of religion is to unite society and establish a connection between the individual and society through religious practices.

M. Eliade, the key originator of the historical and phenomenological direction in religious studies, interpreted the category of "sacred" as the most important way to express the essence of religion. The way he sees, any object, which is considered by the subject as something greater than that provided by nature, is defined as sacred in the secular environment [19, p. 18]. Instead, modern researchers, elucidating the genesis of religion, pay attention to the ways of dividing the secular, sacred and sacral. In this context, the sacral is a predicate of those entities that are the object of worship. Religious practices combine the uniqueness of the individual and universality. According to L. Astakhova, referring to the universality and integrity of the whole and the part, the actors and the system in general, religions preserve themselves in terms of integrity and immutability. On the other hand, binary oppositions contain a kind of basis of communicative codes of the social system [20, p. 11].

It should be mentioned that the sacral cannot be understood by reducing it to one essential feature, there is a need to analyze the construction of the category and justify the legitimacy of their use. The term "sacred" has long been used as an object or model to denote the forbidden realm of the supernatural. The term "sacred" was widely-used as the only source for all religions. Thus, all these categories express a specific feature of phenomena and their manifestations. However, within religious practices, it is important to distinguish between their empirical existence and belief in their reality. Instead, there is a need to formulate a category objectified within philosophical discourse that has practical application and articulates the necessary boundary properties. This category, from our point of view, is the "Divine", where religion determines the content in the system of hierarchically constructed worlds. As a result, religious rites become not a system of worship, but a system of orientation in the space structures.

The studies of religious cults and rituals as a system of communication between the faithful and the transcendent are based on the theory of communicative action by J. Habermas [21, p. 84-91]. In social systems, action is constituted through communication and attribution as a reduction of complexity. Religious action should be considered in the context of the procedural nature of subject-object relations without their opposition. Communication is an important component that creates elements of religion as a social system. In religious practices, communication and action complement each other in communicative action. Communicative action strengthens traditions, renews cultural potential and contributes to the formation of personality, its acquisition of identity. Concerning communication, acts in the external world that may be interpreted by others as signs of what is being transmitted must be explicitly performed. Gestures, speech, writing, etc. based on body movements are considered to be such acts. Until now, the behaviorist interpretation of communication is justified. But it finds its fallacy, identifying the means of communication, namely the working act, with the meaning of communication. Thus, the performance of religious worship and rites in Christianity is a special type of social action that is of subjective nature. Regardless of their implementation, it can be religious and secular.

The study of the theoretical basis, source and methodological basis of the current scientific problem made it possible to identify key existing positions, approaches to the study of Christology in the theology of Christian churches and to make a number of generalizations. In particular, the analysis of the problem of covering the religious rites of the ancient Slavic and Christian traditions of mundane life of a faithful in the literature is dictated primarily by the fact that fundamental works on its comprehensive study are almost absent. The degree of the issue elab- 
oration and the source base testified to the fragmentary elaboration of the topic in the published editions devoted to philosophy and religious studies. Moreover, the conducted historiographical review and analysis of sources makes it possible to state the existence of significant scientific achievements of foreign and native scientists, in which the theoretical analysis of certain aspects of research, based on both church heritage and own scientific achievements.

The study of works on the problem of religious worship and rites of foreign and native scholars suggests that religious practices should be considered as a set of interpretations and actions performed by people in accordance with their religious beliefs. They are on the border between the normative world of dogmas of a certain religion and the world of religious experience (individual religious experience), and thus appear, as a rule, as an open hermeneutic system, which is realized through cult and manifested in ritual. The latter appears as a holistic system of prescriptions and rules that determine the procedure for joining the numinous. The rite, being the external manifestation and integral part of the ritual, is traditionally considered as an external expression of the internal content of any religious act.

\section{References}

1. Ратушна Т.О. Релігійні практики в соціокультурному просторі Південно-Східного регіону України : дис. ... канд. соціол. наук : 22.00.04. Запоріжжя, 2010. 180 с.

2. Рязанова Л.С. Релігійне відродження в Україні: соціокультурний контекст. Київ : В-во «Біла криниця», 2004. 240 с.

3. Новая философская энциклопедия: В 4 т. / Ин-т философии РАН, Нац. общ-научн. фонд. Москва : Мысль. Т. ІІІ. 2010. 692 с.

4. Москалець В.П. Психологія релігії : посібник. Київ : Академвидав, 2004. 240 с.

5. Кондратьєва В.І. Релігійні практики традиції об'явлення: доктринальні основи, сутнісні особливості, характер функціонування : дис. ... канд. філос. наук : 09.00.11. Київ, 2017. $241 \mathrm{c}$.

6. Релігієзнавчий словник / За ред. А. Колодного і Б. Лобовика. Київ : Четверта хвиля, 1996. 392 c.

7. Безнюк Д. Культ. Религии мира. URL: http://relig.info/kult.

8. Кунцлер М. Літургія Церкви / пер. с нім. монахині Софії. Львів : Свічадо, 2001. 616 с.

9. Кырлежев А. Культ религиозный. Понятия и категории: вспомогательный проект Хронос. URL: http://ponjatija.ru/node/9334.

10. Академічне релігієзнавство : підручник / за науковою ред. професора А. Колодного. Київ : Світ Знань, 2000. 862 с.

11. Богачевська I.В. Християнська наративна традиція: методологія філософсько-релігієзнавчого дослідження. Київ : Світ Знань, 2005. 235 с.

12. Садохин А. Этнология : учебное пособие. Москва : Гардарики, 2006. 286 с.

13. Ритуал. Толковый словарь Ушакова. Словари и энциклопедии на Академике. URL: http://dic.academic.ru/dic.nsf/ushakov/1010498

14. Ожегов С. Толковый словарь русского язика. Электронная библиотека bookz.ru. URL: http://bookz.ru/authors/ojegov-si-6vedova-nu/ozhegow_diction/page149-ozhegow_ diction.html.

15. Байбурин А. Ритуал в системе знаковых средств культуры. Этнознаковые функции культуры. Москва : Наука, 1991. С. 23-35.

16. Смит У. Лекции о религии семитов. Антология. Т. 1: Классики мирового религиоведения. Москва : «Канон +» РООИ «Реабилитация», 1996. 496 с.

17. Тайлор Э. Миф и обряд в первобытной культуре. / Пер. с англ. Д.А. Коропчевского. Смоленск : Русич, 2000. 624 с. 
18. Дюркгейм Э. Элементарные формы религиозной жизни. Мистика. Религия. Наука. Классики мирового религиоведения. Антология; / пер. с англ., нем., фр.; сост. и общ. ред. А.Н. Красникова. Москва : Канон+, 1998. С. 174-231.

19. Элиаде М. Священное и мирское / пер. с фр., предисл. и коммент. Н.К. Гарбовского. Москва : Изд-во МГУ, 1994. 144 с.

20. Астахова Л.С. Динамика современных религиозных практик в структурах повседневности : автореф. дис. ... д-ра филос. наук. Ленинградский гос. ун-т им. А.С. Пушкина. Санкт-Петербург, 2013. 39 с.

21. Габермас Ю. Комунікативна дія і дискурс - дві форми повсякденної комунікації / пер. з нім. Ситниченко Л. Першоджерела комунікативної філософії. Київ : Либідь, 1996. C. 84-91.

\section{КУЛЬТОВА ПРАКТИКА У СФЕРІ ПОВСЯКДЕННОГО БУТТТЯ РЕЛІГІЇ}

\section{Крістіна Кваша}

Житомирський державний університет імені Івана Франка, кафедра філософії та політологіі

вул. Велика Бердичівська, 40, 10008, м. Житомир, Украӥна

У статті аналізується змістове навантаження поняття «релігійний культ», яке на соціокультурному рівні проявляється як комплекс ритуалів та обрядів, спрямованих на вшанування Бога з боку прихильників тієї чи іншої релігії. Показано, що основою та зовнішнім виявом релігійного культу є ритуал, який своєю чергою може передбачати цілий комплекс обрядових дій. Розмежовано поняття «ритуал» та «релігійний обряд». Встановлено, що ритуал - це чіткий порядок обрядових дій, яких людина повинна дотримуватися незалежно від внутрішнього стану душі й індивідуальних переживань. Підкреслено поліфункціональність ритуалу, що виступає дієвим чинником збереження спільноти в кризовій ситуації, засобом трансляції соціальної спадщини та збереження традиції. Крім того, ритуал, постаючи як система різноманітних знакових систем, формує почуття соціального благополуччя й унікальності. Відмежовуючись від семантичної спорідненості релігійного обряду та ритуалу у давньослов'янських і християнських традиціях, доведено змістову та ієрархічну їх відмінність, підкреслюючи, що обряд варто розглядати як порядок зовнішніх допоміжних дій, які або ж супроводжують ритуал, або ж спрямовані на освячення життєвих потреб людини чи спільноти.

Відносно вільний простір осмислення та інтерпретації релігійних практик у повсякденному житті віруючих зумовив варіативний характер практик, демонстрацію сфери взаємовпливу церковного й світського дискурсів. Особливістю буденного життя вірян є орієнтування на здійснення обрядів, характерною рисою яких є домінування ритуально-обрядового складника релігійності й ототожнення сутності християнства переважно із зовнішніми проявами церковності. Аналіз буденних практик віруючих різних релігійних організацій демонструє не лише поєднання світського й церковного дискурсів, а й виявляє ступінь гнучкості, адаптивності практик до соціокультурного середовища. Дослідження релігійних практик дає змогу визначити точки перетину світського й клерикального дискурсів на етноконфесійному полі.

Ключові слова: релігійна практика, обряд, культ, ритуал, христологія, релігійна ідентичність. 